\title{
FATORES DETERMINANTES DA COMPOSIÇÃO E ENDIVIDAMENTO DAS EMPRESAS LISTADAS NA BM\&FBOVESPA ENTRE OS MANDATOS PRESIDENCIAIS LULA (2007- 2010) E DILMA (2011-2014) ${ }^{1}$
}

\section{DETERMINING FACTORS COMPOSITION AND INDEBTEDNESS OF THE COMPANIES LISTED ON THE BM \& FBOVESPA BETWEEN THE LULA'S PRESIDENTIAL TERM (2007-2010) AND DILMA'S PRESIDENTIAL TERM (2011-2014)}

\section{Lara Fabiana Dallabona $^{2}$}

Doutora em Ciências Contábeis e Administração pela Fundação Universidade Regional de Blumenau - FURB Universidade do Estado de Santa Catarina - UDESC

lara.dallabona@udesc.br

https://orcid.org/0000-0002-7158-247X

\section{Michele Gonçalves}

Mestre em Ciências Contábeis pela Fundação Universidade Regional de Blumenau - FURB Serviço Nacional de Aprendizagem Industrial

eloiza gesser@hotmail.com

https://orcid.org/0000-0003-0201-9736

\section{Eloiza Gesser Radloff}

Pós-Graduada em Controladoria e Finanças pela Universidade do Estado de Santa Catarina - UDESC michele.goncalves@udesc.br https://orcid.org/0000-0002-1297-3534

\section{RESUMO}

Objetivo: Analisar quais variáveis econômico-financeiras explicam a composição do endividamento das cem maiores e menores empresas listadas na BM\&FBovespa entre os mandatos presidenciais Lula (2007-2010) e Dilma (2011-2014).

Analisar variáveis que explicam a composição do endividamento das empresas nos mandatos presidenciais Lula (2007-2010) e Dilma (2011-2014).

Método: Utilizou-se regressão linear múltipla.

Resultados: Os resultados apontaram que em 2007, as variáveis ROA, ROE, ativo total, patrimônio líquido, liquidez geral e liquidez corrente apresentaram significância em uma das três variáveis dependentes. A variável crescimento apresentou significância em apenas uma variável dependente entre os anos 2009 e 2011. As variáveis liquidez geral e liquidez corrente apresentaram significância em todos os períodos analisados, diferente da variável ROE, que não apresentou

\footnotetext{
${ }^{1}$ Artigo recebido em: 30/11/2017. Revisado por pares em: 15/01/2018. Reformulado em: 15/06/2018. Recomendado para publicação em: 20/06/2018 por Luiz Felipe de Araújo Pontes Girão (Editor Geral). Publicado em: 31/08/2018. Organização responsável pelo periódico: UFPB

2 Endereço: Rua Dr. Getúlio Vargas, 2822, Bela Vista - Ibirama, SC, 89140-000.

DOI: https://doi.org/10.22478/ufpb.2318-1001.2018v6n3.37372
} 
significância em 2013. A variável ROA também apresentou significância em todos os períodos. A variável Patrimônio Líquido apresentou significância em relação a algumas variáveis dependentes. Por sua vez, as variáveis rentabilidade do ativo e liquidez geral apresentaram maior significância em relação a variável dependente endividamento geral nos períodos analisados.

Contribuições: Conclui-se que apenas a variável composição do endividamento apresentou diferença entre os dois períodos (sobre as 100 maiores), observando que no primeiro período (20072010) foi explicado por sete variáveis independentes, quais sejam: Liquidez geral, Liquidez corrente, Patrimônio líquido, ROA, Ativo total e Crescimento, enquanto que no segundo período (20102014), foi explicado apenas pela liquidez corrente.

Palavras-chave: Endividamento. Determinantes do Endividamento. Endividamento Geral. BM\&FBovespa.

\section{ABSTRACT}

Objective: To analyze which economic and financial variables explain the composition of the debt of the 100 largest and smallest companies listed on the BM\&FBovespa in the last presidential term (2007-2010 Lula government and 2011-2014 Dilma government).

Background: Analyzing the variables that explain the composition of companies' indebtedness, becomes relevant to analyze the organizational competitive advantage in the presidential periods.

Method: Multiple linear regression was used.

Results: The results show that in 2007, the variables: ROA, ROE, total assets, net worth, general liquidity and current liquidity presented significance in any of the three dependent variables. The variable growth presented significance in some dependent variable only in the years of 2009 and 2011.The variables general liquidity and current liquidity presented significance throughout the analyzed period, since the ROE variable did not show significance only in the year 2013, while the ROA variable presented significance in all periods. As for the variable Net Equity, it also presented significance to some dependent variables. The variables asset profitability and general liquidity presented a higher frequency of significance in relation to the dependent variable general indebtedness in the whole analyzed period.

Contributions: It is concluded that observing the data under the presidential term, only the dependent variable composition of the indebtedness showed great difference between the two trems (over the 100 majors), noting that in the first term (2007-2010) is explained by seven independent variables, namely: general liquidity, current liquidity, net worth, ROA, total assets and growth, while in the second term (2010-2014) is explained by only one variable, current liquidity.

Keywords: Indebtedness. Determinants of Indebtedness. General Indebtedness. BM\&FBovespa.

\section{INTRODUÇÃO}

Diversos são os estudos que tratam dos níveis de endividamento das empresas. Esta pesquisa se integra em mais um esforço para descobrir determinantes do endividamento das empresas no cenário econômico. Um dos estudos mais citados entre os pesquisadores é o dos precursores da análise de estrutura de capital: Modigliani e Miller (1958). Estes autores são apontados como os 
pioneiros nos estudos a respeito das decisões de financiamento/investimento. Outro pesquisador é Durand (1952), que alega haver uma estrutura de capital ótima. A partir destes nomes, gestores, contadores e economistas tem se aperfeiçoado e se aprofundado sobre este tema, que se remete até os tempos modernos.

Nakamura, Martin e Kimura (2004) afirmam que a maioria das teorias que falam a respeito da estrutura de capital procuram um modelo ótimo em que o capital próprio e o capital de terceiros combinados tragam a maximização da riqueza dos acionistas. Seguindo tal linha de pensamento, Brealey e Myers (1991) questionam os pensamentos de Modigliani e Miller (1958), os quais afirmavam de que as decisões de financiamento/investimento não influenciavam na formação do valor de uma empresa.

Se de fato a política de financiamentos/investimentos das empresas fosse, de certa forma, irrelevante, os níveis de endividamento entre as empresas apresentariam variações de forma aleatória de uma empresa para outra. Na prática, porém, muitos estudos afirmam que existe um padrão congênere no perfil econômico-financeiro de empresas (Brealey \& Myers, 1991).

Baseando-se em todos estes fatos, é relevante o interesse das empresas de entender e descobrir o que realmente influencia no seu endividamento, como um ponto crítico dentro do sistema que engloba todas as partes que mantêm a engrenagem financeira da empresa em movimento. Brito, Corrar e Batistella (2007) enfatizam que apesar deste tema ser discutido por mais de 50 anos no meio científico, a heterogeneidade das evidências empíricas mostra que tal assunto ainda precisa ser estudado de maneira contínua, envolvendo diferentes perspectivas que contribuam com o entendimento do tema, como, por exemplo, períodos de crises, influencias partidárias, entre outros.

Conforme Rosa e Costa (2014), o Brasil foi consideravelmente afetado pela crise em 2008, presenciando, dentre outros fatores, a redução dos preços das ações de empresas, queda no consumo dos produtos, problemas financeiros na produção e distribuição, crédito afetado e o descrédito dos investidores. Como a crise mundial afetou diretamente as empresas, os autores destacam complexidade na mensuração dos impactos na situação econômica e financeira das empresas.

Nesse sentido, Bernardelli e Bernardelli (2016) salientam que a crise política que alcançou o Brasil, contribuiu demasiadamente para o declínio econômico. A queda de indicadores macroeconômicos foi maior a partir de 2014 e seguiu até 2017. Consequentemente, o mercado financeiro foi moldado por essas oscilações, em que um aumento na incerteza de estimativas de longo prazo, por exemplo, acarretou um aumento na volatilidade do mercado.

Ristoff (2011) aponta que para o país reforçar o papel de ator global, integrando o esforço do governo brasileiro para promover a competitividade dos produtos nacionais, favorecendo a integração econômica dos países da América do Sul, contou com um processo acelerado da internacionalização com o apoio do BNDES e das empresas nacionais. De acordo com Ristoff (2011), o BNDES teve aumento da participação na economia brasileira, durante os dois mandatos presidenciais do governo Lula: Garantiu crédito a políticas de caráter anticíclico, objetivando amenizar os efeitos da crise e mantendo o crescimento econômico do país. Com esse apoio do governo, o estado passou a atuar em áreas consideradas estratégicas e estimulou o desenvolvimento econômico.

Geralmente as empresas se baseiam em resultados de indicadores econômico-financeiros para analisar o seu desempenho e desenvolvimento econômico. De acordo com Marques (2004), Iudícibus (2008) e Mello et al. (2010), a contabilidade pode ser considerada uma das melhores e mais importantes fontes de informação e estratégia para os negócios e para a avaliação do desempenho. Desta forma, a literatura apresenta, dentre os indicadores, dois grupos obtidos por meio das informações contábeis, como, por exemplo, os índices de liquidez e os índices de rentabilidade que auxiliam os gestores nas tomadas de decisões. 
Os indicadores de liquidez demonstram a capacidade da empresa de honrar com seus compromissos financeiros (SILVA, 2007). Enquanto o grupo de rentabilidade revela a situação econômica e a capacidade de elevar ao máximo os lucros. Tais indicadores são ferramentas fundamentais para avaliar a empresa e sua gestão (CARVALHO; SANTOS; RÊGO, 2010). Para Braga et al. (2004), esses dois grupos de índices (liquidez e rentabilidade) devem apresentar equilíbrio para demonstrar uma boa saúde econômico-financeira da empresa, o que permite relacioná-los à composição do endividamento.

Sabendo que o endividamento descontrolado pode vir causar a "quebra" da empresa, tornase fato que uma das mais valiosas informações para os empresários é descobrir de que forma, dentro da estrutura da empresa, acontece o aumento ou a diminuição do nível de endividamento. A questão é saber qual variável influencia o endividamento: Tamanho? Liquidez? Rentabilidade? Crescimento?

Assim, se faz pertinente analisar o endividamento das empresas com ações negociadas em bolsa de valores, durante mandatos presidenciais distintos (Lula e Dilma), pois propicia investigar se há influência de variáveis macroeconômicas e financeiras na estrutura de capital das empresas, fato que se busca investigar por meio da pergunta de pesquisa: Quais variáveis econômicofinanceiras explicam a composição do endividamento das cem maiores e menores empresas listadas na BMEFBovespa nos últimos mandatos presidenciais (governo Lula (2007-2010) e governo Dilma (2011-2014)? Objetiva-se analisar quais variáveis econômico-financeiras explicam a composição do endividamento das cem maiores e menores empresas listadas na BM\&FBovespa nos últimos mandatos presidenciais (2007-2010 governo Lula e 2011-2014 governo Dilma).

Faé, Goulart e Abdala (2016) mencionaram que a eleição de Lula era esperada pela maioria da população, que ansiosamente aguardavam por mudanças sociais que foram apresentadas pelo Partido dos Trabalhadores (PT), dentre elas o combate à fome, investimentos em educação, moradia, além de outras ações para retomar o desenvolvimento econômico.

O governo Lula, conforme relatos de Santos et al. (2013), deu continuidade à política econômica do governo do Fernando Henrique Cardoso e mesmo diante da crise financeira de 2008, já no segundo mandato presidencial, pontos positivos foram identificados, como: $\mathrm{O}$ controle das taxas de inflação em menores níveis, incentivo na atividade de exportação, diversificação na área de investimentos, estímulo ao microcrédito, redução nas taxas de desemprego e crescimento da classe média. Além disso, a alavancagem na produção de cana de açúcar e a descoberta e implantação de políticas para o pré-sal, se tornaram fatores importantes para resultados econômicos favoráveis.

Em 2011, Dilma é eleita presidente do Brasil, objetivando dar continuidade ao programa do governo Lula. A priori, utilizada como para os principais investimentos em projetos e programas, o incentivo ao crescimento econômico, o que para isso, se renovava a necessidade de estabilidade macroeconômica e controle de inflação. A atividade de exportação foi evidenciada, como meio de equilíbrio da balança comercial, tal como o estímulo na competividade dos produtos no mercado interno e externo (Faé, Goulart \& Abdala, 2016). Nesse contexto, considera-se relevante o governo, visando estabelecer planos econômicos, pautar-se em informações confiáveis sobre o cenário nacional, pois as medidas utilizadas podem afetar consideravelmente à sociedade e a estrutura das empresas no que se refere ao endividamento e crescimento organizacional.

Para Cagnin et al. (2013) entre 2011 e 2012, puderam ser identificados três períodos distintos no que concerne a orientação da política macroeconômica do governo Dilma. No primeiro período, as políticas monetária e fiscal tiveram um caráter restritivo, no intuito de minimizar a situação econômica do país e, assim, conter a aceleração inflacionária naquele período eleitoral. A diretriz de política Dilma alinhou-se às mesmas iniciativas adotadas no mandato Lula, que procurava a redução dos riscos associados à forte expansão dos empréstimos com recursos livres às famílias, mas que também contribuíram para a desaceleração da demanda. 
Desta forma, este estudo é justificado pelo fato de que, mesmo que existam trabalhos que abordam o endividamento das empresas, poucos consideram variáveis em períodos específicos de mandatos presidenciais, mesmo que alguns, de forma indireta, acabaram analisando tais períodos, mas não forneceram evidencias governamentais para os resultados. Além disso, a abordagem dos mandatos presidenciais para análise da composição e endividamento das empresas, se torna relevante à medida que as características de investimentos, as práticas de juros, o desenho macroeconômico e outras variáveis, também possam explicar as alterações da estrutura organizacional.

\section{FUNDAMENTAÇÃO TEÓRICA}

Com base nas evidências apresentadas por Rosa e Costa (2014), a crise de 2008 afetou diretamente as empresas de todo o mundo, inclusive as empresas brasileiras. $\mathrm{O}$ valor das ações de empresas listadas na bolsa de valores, caíram consideravelmente, o consumo do mercado interno desacelerou e os problemas financeiros aumentaram. A influência da crise na situação econômica e financeira das empresas foi notória, contudo a mensuração desse impacto é abstrata e difícil de se prever.

Conforme Lopes et al. (2016), em 2008 o mundo sentiu a pior crise desde 1929. Esta crise se originou nos Estados Unidos, após a queda da taxa de juros, quando as instituições financeiras, em uma manobra para aumentar as concessões de crédito, começaram a explorar o mercado de alto risco. Porém, o aumento do volume de crédito acarretou numa valorização desproporcional dos imóveis. Acioly et al. (2009) consideram que a crise financeira de 2008 também pode ser explicada por fatores macroeconômicos.

Os primeiros efeitos da crise de 2008, foi a alta do dólar, redução inicial da liquidez, disponibilidade de crédito e queda significativa no preço das commodites (Moreira \& Soares, 2010; Maranho, Fonseca \& Frega, 2015). Moreira e Soares (2010) destacam que as crises geralmente surgem de uma "bolha" na economia, em que se origina pelo excesso de endividamento, tanto por parte do governo, quanto das empresas e famílias.

Devido à dinamicidade do mercado, é necessário que seja estabelecida uma forma de avaliar o desempenho econômico e financeiro das empresas, a fim de estabelecer sua posição em relação à concorrência e ainda responder questões de investidores ou stakeholders (Lunardi et al. 2017). Geralmente o desempenho econômico-financeiro das empresas é mensurado com base em dados contábeis, porém variáveis macroeconômicas podem ser relevantes para estudos científicos, visando identificar variáveis que possam explicar o desempenho organizacional.

No Brasil, destaca-se a forte influência do fator político que, quando em crise, impactam negativamente o desempenho econômico do país. Com o aumento da incerteza, cresce também a instabilidade do mercado (Bernardelli \& Bernardelli, 2016). Rosa e Costa (2014) realizaram um estudo que compreendeu o período 2007 a 2009, correspondendo à época da crise subprime, analisaram três grupos de indicadores de desempenho das empresas contempladas, sendo eles: Liquidez; Rentabilidade e Endividamento. Obtiveram resultados consideráveis, verificaram que os índices de liquidez se mantiveram constantes no período analisado, que em hipótese era para ter diminuído. Os índices de rentabilidade apresentaram queda nos dois primeiros anos de análise, e no terceiro, um aumento (comparado com 2007), isso devido ao resultado líquido.

No período de 2016, em pleno colapso financeiro, alavancada pela crise política e fiscal no Brasil, o cuidado necessário para a administração financeira das empresas precisa ser ainda mais minucioso. Essa preocupação com a situação econômica do Brasil vem fazendo com que empresários adiem investimentos e novos empreendedores aguardem por momentos menos incertos para iniciar algum projeto. Essas atitudes causam uma recessão econômica. 
Como o endividamento descontrolado pode vir causar a "quebra" da empresa, torna-se fato que uma das mais valiosas informações para os empresários é descobrir onde, especificadamente dentro da estrutura da empresa, acontece o aumento ou a diminuição do nível de endividamento e, assim, seus gestores terem maior controle sobre seus níveis de endividamento. A questão é saber qual fator influencia o endividamento: Tamanho? Liquidez? Rentabilidade? Crescimento? Desta forma, torna-se indispensável comprovar por meio de pesquisa científica, qual ou quais fatores influenciam o endividamento das empresas.

Para Santos, Pimenta Júnior e Cicconi (2008) as decisões relacionadas ao financiamento organizacional envolvem uma série de questões e resultam na escolha de um mix de fontes de recursos de longo prazo que tenham o objetivo de maximizar os valores dos projetos à que se referem na busca por uma estrutura de capital ótima, possibilitando reduzir o custo de capital das empresas por meio da combinação ideal de capital próprio e de terceiros.

Borges et al. (2017) destacam que quanto maior for a independência de capital de terceiros, a empresa mais solvente será. Desta forma, o endividamento se torna uma estratégia que as empresas utilizam para sua continuidade, desde que gerenciada de forma eficiente. Fatores externos e internos podem impactar no prazo do endividamento e consequentemente, variáveis como o tamanho, a liquidez, a taxa de juros e o nível de desenvolvimento do país podem influenciar direta ou indiretamente o endividamento das empresas (Martins \& Terra, 2015). Silva et al. (2016) corroboram com essa ideia, ao mencionarem que as dívidas podem ser impactadas pela macroeconomia, fatores específicos de cada país, PIB, inflação e outros fatores econômicos e financeiros. O tamanho, também pode influenciar o endividamento das empresas.

$\mathrm{Na}$ busca de melhor entendimento sobre uma estrutura ótima de capital estudos nacionais e internacionais foram desenvolvidos abrangendo os níveis de endividamento com determinantes contábeis de liquidez, rentabilidade, além de tamanho e crescimento da empresa e da taxa básica de juros. Dentre os estudos apresentados, cita-se a pesquisa realizada por Sant'Ana (2001) visou demonstrar uma correlação significativa entre os índices de rentabilidade e os índices de endividamento das empresas brasileiras entre 1996 e 2000. Segundo o autor, pressupõe-se que o administrador consiga estimar o valor de rentabilidade em função do endividamento. Com a utilização de métricas de correlação, os dados analisados permitiram identificar significância entre os índices estudados. O estudo apresentado se faz pertinente para a pesquisa, visto que abrangeu, em sua análise, dois períodos presidenciais do Fernando Henrique Cardoso, o que pode ser útil para fins comparativos com os resultados do estudo do estudo proposto.

Silva et al. (2016) afirmam que embora diversas variáveis possam afetar as decisões de financiamento de uma organização, países situados na América Latina podem sofrer com fatores macroeconômicos, como: Taxa de crescimento do PIB (Produto Interno Bruto), Taxa de inflação, entre outros. Assim, o estudo busca evidenciar se essas características podem influenciar na estrutura de capital das empresas analisadas e se o período também é fator preponderante para o endividamento das mesmas.

Quanto à pesquisa de Brito, Corrar e Batistella (2007), objetivaram descobrir se há correlação entre os índices de endividamento e risco, tamanho, composição dos ativos, rentabilidade e crescimento. A amostra concentrou-se em empresas de capital aberto e de capital fechado. As variáveis dependentes de estrutura de capital selecionadas foram endividamento total, endividamento a curto prazo e endividamento a longo prazo. Os resultados revelaram que os fatores risco, tamanho, composição dos ativos e crescimento são determinantes da estrutura de capital das empresas, enquanto que o fator rentabilidade não se mostrou determinante.

Laureano (2008), buscou descobrir a relação dos fatores composição dos ativos, lucratividade, liquidez, tamanho, taxa de juros e volatilidade com os níveis de endividamento a curto prazo e também a longo prazo. A técnica estatística utilizada foi a técnica de efeitos fixos para dados em 
painel que, segundo a autora, garante o consequente ganho de eficiência na estimação dos coeficientes. No curto prazo, a autora determinou que quanto menor a tangibilidade, menor o lucro, menor a sua liquidez, menor for o seu tamanho e menor forem os juros praticados no mercado, mais as empresas tenderão a se endividar. Os fatores composição do ativo e tamanho aplicado em curto e longo prazo demonstraram que as empresas que são maiores e com mais ativos tangíveis consequentemente trocam o endividamento a curto prazo para o endividamento a longo prazo. O estudo de Laureano (2008) se torna relevante para fins comparativos com essa pesquisa, por considerar o período de análise, visto que envolve o primeiro mandato do governo Lula.

Bastos e Nakamura (2009) relacionaram a liquidez corrente, rentabilidade do ativo (ROA), crescimento e tamanho com o nível de endividamento de empresas. Sendo assim, quanto maior valor do fator específico descrito anteriormente, maior é o nível de endividamento. Além da utilização das relações descritas pelos autores supracitados, esta pesquisa ainda procura relacionar outros fatores, como a taxa SELIC, a liquidez corrente, a liquidez geral e o retorno sobre o patrimônio (ROE). O estudo de Bastos e Nakamura (2009) permite comparar resultados com a pesquisa desenvolvida, principalmente no que tange à variável taxa SELIC, pois nem todos os estudos envolvendo endividamento, as utilizam.

Fank, Angonese e Toledo Filho (2010), objetivaram descobrir quais seriam os determinantes de endividamento das empresas. A seleção da amostra foi fixada em 300 empresas nacionais e a determinação da amostra se deu por meio do volume de vendas dessas empresas. Os fatores analisados pelos autores foram a rentabilidade, o tamanho da empresa e também a oportunidade de crescimento. Os resultados demonstraram que há relação entre o nível de endividamento e a rentabilidade do patrimônio líquido, mas que não há entre o tamanho da empresa e a oportunidade de crescimento.

Espinola e Kayo (2013) investigaram quais são os determinantes de endividamento para dívidas totais de mercado no período de crise financeira global. Os determinantes estudados pelo autor foram lucratividade, expectativas de crescimento, risco de falência, inovação, tangibilidade e tamanho. A amostra foi constituída de dados financeiros de 1592 empresas de capital aberto dos Estados Unidos dos períodos de 1992 a 2010. A metodologia utilizada foi a regressão múltipla com dados em painel, as variáveis de endividamento utilizadas pelo autor classificaram-se em: Endividamento de longo prazo, endividamento de curto prazo e endividamento total. Foi possível observar que houve uma confirmação de mudanças no comportamento da estrutura de capital das empresas durante a crise financeira global. Os autores declararam que a lucratividade, a tangibilidade e o tamanho se mostraram importantes na análise durante a crise financeira global. As demais variáveis não se tornaram significativas, pois perderam seu poder explicativo, segundo os resultados obtidos por Espinola e Kayo (2013).

Para investigar a influência de diferentes grupos de fatores na variância da maturidade do endividamento corporativo na América Latina, Martins e Terra (2015), utilizaram a análise fatorial para mensurar o nível de endividamento e a qualidade das instituições dos países da amostra. Os resultados demonstraram que o tamanho, a liquidez, a taxa de juros e o desenvolvimento financeiro são os determinantes das dívidas. Os autores sugeriram, que um ambiente institucional que apresenta maior qualidade, um setor financeiro mais desenvolvido e com maior estabilidade macroeconômica, podem ser elementos relevantes para a determinação da maturidade do endividamento das empresas em geral.

Analisar os fatores determinantes do endividamento das companhias do setor de telecomunicações brasileiro à luz das Teorias do Static Trade-Off (STT) e da Pecking Order (POT), no período de 2002 a 2013, foi objetivo do estudo de Prazeres et al. (2015). O estudo vinculou como variáveis dependentes o endividamento de curto prazo e o endividamento de longo prazo, e como variáveis independentes, a rentabilidade, a tangibilidade, o crescimento, o tamanho e o risco. Houve 
relação negativa entre a rentabilidade, tamanho e risco com o endividamento de curto prazo, e relação negativa entre o tamanho e o risco com o endividamento de longo prazo. O estudo por ora apresentado, será relevante para fins comparativos com a pesquisa desenvolvida, tanto no contexto das variáveis utilizadas, quanto no período analisado, pois mesmo de forma indireta, ambos utilizaram períodos presidenciais.

Silva et al. (2016) verificaram o efeito na crise em empresas do Brasil, Rússia, Índia e China (BRICS) com diferentes níveis de endividamento. Os efeitos da crise mostraram diferentes intensidades de endividamento para as empresas pertencentes ao BRICS, o que já era previsto, pois possuem diferentes características econômicas e institucionais. Para as empresas brasileiras, os resultados indicaram que os principais determinantes da estrutura de capital não afetaram a dívida de longo prazo, considerando que os resultados não foram estatisticamente significativos.

Borges Jr. et al. (2017), examinaram o efeito do endividamento de longo prazo no desempenho de empresas brasileiras e latino-americanas, envolvendo neste período, o cenário anterior e posterior a crise mundial de 2008, compreendendo o período de 2007 até 2015. Além das empresas listadas nas bolsas de valores do Brasil, estiveram as listadas no Chile, Argentina, Colômbia, México e Peru. Os dados demonstraram que, com exceção do Brasil, houve relação negativa entre o endividamento de longo prazo e o desempenho das empresas, sendo que no Brasil, os resultados foram inconclusivos.

Com base nos estudos já desenvolvidos, esta pesquisa buscou analisar algumas variáveis utilizando três índices de endividamento: Geral, que mede a "fatia" do capital pertencente a terceiros em relação ao valor do ativo total; Composição do endividamento, que mede a proporção de obrigações a curto prazo em relação as obrigações totais da empresa, desta forma esclarecendo que tipo de política de captação de recursos foi utilizada pela empresa e se a concentração ocorreu a curto prazo ou a longo prazo; e Grau de endividamento, que demonstra quanto do total de recursos concentra-se em capital de terceiros.

\section{PROCEDIMENTOS METODOLÓGICOS}

A pesquisa caracterizou-se como descritiva, documental e quantitativa. A população envolveu 328 empresas listadas na BM\&FBovespa, conforme dados disponíveis no site da, até então, BM\&FBovespa em 2014. Considerando que o período analisado compreendeu 2007 até 2014, muitas empresas não possuíam informações disponíveis sobre as variáveis investigadas, com isso, optou-se por uma amostra intencional, da qual compreendeu as 100 (cem) maiores e 100 (cem) menores empresas da BM\&FBovespa. O critério para classificá-las como maiores e menores, foi o valor do ativo total. Àquelas que não apresentavam dados necessários, foram substituídas pelas empresas subsequentes, para totalizar a amostra de 200 empresas.

Os dados numéricos utilizados para os cálculos dos índices foram coletados dos balanços patrimoniais, demonstrativos de resultado de exercício e da base de dados Economática ${ }^{\circledR}$. Todos os valores foram retirados do período 2007-2014, exceto os valores para o cálculo da variável Crescimento, em que se utilizaram os valores do ativo do ano de 2015.

Observou-se que o período estudado compreende a duas legislaturas pertencentes a mesma estrutura governamental, não havendo desta forma, grandes mudanças de decisão política no mercado. Quanto aos dados da taxa SELIC, utilizados como proxy de uma das variáveis independentes que foram selecionadas para a análise, os mesmos foram coletados do site do Banco Central do Brasil. 
As variáveis de endividamento selecionadas para a pesquisa são constituídas das nomenclaturas: Endividamento Geral e Composição do Endividamento, baseados nos autores Iudícibus (2009) e Matarazzo (2010). As fórmulas utilizadas para as variáveis dependentes e independentes são demonstradas no Quadro 1.

Quadro 1 - Indicadores de endividamento

\begin{tabular}{|c|c|c|c|}
\hline Variável & Tipo & Fórmula & Autor \\
\hline $\begin{array}{l}\text { Endividamento } \\
\text { Geral }\end{array}$ & Dependente & $\frac{\text { Passivo Circulante+ Passivo Não-Circulante }}{\text { Ativo Total }} \times 100$ & Iudícibus (2009) \\
\hline $\begin{array}{l}\text { Composição do } \\
\text { Endividamento }\end{array}$ & Dependente & $\begin{array}{c}\frac{\text { Passivo Circulante }}{\text { Passivo Circulante + Passivo Não-Circulante }} \\
\text { Patrimônio Líquido }\end{array}$ & $\begin{array}{l}\text { Matarazzo (2010) } \\
\text { Iudícibus (2009) }\end{array}$ \\
\hline $\begin{array}{l}\text { Tamanho da } \\
\text { empresa }\end{array}$ & Independente & Valor do ativo Total & $\begin{array}{l}\text { Angonese, Santos e } \\
\text { Lavarda (2010) }\end{array}$ \\
\hline Crescimento da empresa & Independente & $\begin{array}{l}\text { Variação Dos Ativos ao longo do tempo amostral } \\
\text { estudado }\end{array}$ & Jorge e Armada (2001) \\
\hline ROA & Independente & $\begin{array}{l}\frac{\text { Lucro Líquido }}{\text { Total do Ativo }} \times 100 \\
\end{array}$ & Costa Jr e Lemes Jr (2006) \\
\hline ROE & Independente & $\frac{\text { Lucro Líquido x } 100}{\text { Patrimônio Líquido }}$ & Costa Jr e Lemes Jr (2006) \\
\hline TAXA SELIC & Independente & Valor médio da taxa SELIC & Laureano (2008) \\
\hline $\begin{array}{l}\text { Liquidez } \\
\text { Corrente }\end{array}$ & Independente & Ativo Circulante / Passivo Circulante & Matarazzo (2010) \\
\hline $\begin{array}{l}\text { Liquidez } \\
\text { Geral }\end{array}$ & Independente & $\begin{array}{c}\text { Ativo Circulante + Ativo Não-Circulante } \\
\text { Passivo Circulante + Passivo Não-Circulante }\end{array}$ & Matarazzo (2010) \\
\hline $\begin{array}{l}\text { Patrimônio } \\
\text { Líquido }\end{array}$ & Independente & Valor do patrimônio líquido & Costa Jr e Lemes Jr (2006) \\
\hline
\end{tabular}

Fonte: Elaborado pelas autoras.

O método estatístico utilizado para a mensuração de dados foi a Regressão Linear Múltipla. Utilizou-se para a análise o software Statistical Package for the Social Sciences (SPSS), em que foram utilizadas duas equações conforme modelo a seguir apresentados:

Modelo 1: $E N D \_G E R=\beta 0+\beta 1$ TAM $+\beta 2$ CRESC $+\beta 3 R O A+\beta 4 R O E+\beta 5$ TSE $+\beta 6 L C O+\beta 7$ $L G E+\beta 8 P L+e$

Modelo 2: $C O M \_E N D=\Phi 0+\Phi 1 T A M+\Phi 2 C R E S C+\Phi 3 R O A+\Phi 4 R O E+\Phi 5 T S E+\Phi 6$ $L C O+\Phi 7 L G E+\Phi 8 P L+e$

O Endividamento geral e a Composição do endividamento foram categorizadas como variáveis dependentes. O tamanho da empresa, Crescimento, ROA, ROE, Taxa Selic, Liquidez corrente, Liquidez geral e Patrimônio líquido foram categorizadas como variáveis independentes.

\section{ANÁLISE DOS DADOS}

Essa seção apresenta a regressão linear envolvendo as 100 maiores e menores empresas da BM\&FBovespa no período de 2007 até 2014. É relevante destacar que só serão apresentadas as 
variáveis independentes que apresentarem significância em relação à variável dependente, ou seja, coeficientes com significância até 0,05 .

Para verificar a validade dos modelos, foram aplicados alguns testes de pressupostos. Utilizou-se o pressuposto da multicolinearidade para verificar o comportamento semelhante das variáveis conforme sugerem Fávero et al. (2009), por meio do Variance Inflation Factor (VIF) e o Durbin-Watson. O VIF indica o nível de multicolinearidade, em que até 1 não representa; de 2 a 10 multicolinearidade aceitável e acima de 10, problemático (Hair et al., 2009; Gurajati, 2006). Já o teste Durbin-Watson, conforme explicam Fávero et al. (2009), destacam que quanto mais próximo de 2, menor será a chance de ocorrer problemas com as correlações entre as variáveis dos modelos analisados.

Na Tabela 2, apresentam-se os dados de correlação entre a variável "composição do endividamento" com as variáveis independentes das maiores e menores empresas estudadas. Para testar a validade do modelo de regressão, procedeu-se o teste $\mathrm{F}$, o qual permite testar a significância da regressão.

Tabela 2- Correlação entre as variáveis independentes das maiores e menores empresas com a variável dependente Composição do Endividamento

\begin{tabular}{c|c|c|c|c|c|c|c|c}
\hline \hline \multirow{2}{*}{ Ano } & Empresas & $\mathbf{R}$ & $\mathbf{R}^{\mathbf{2}}$ & $\begin{array}{c}\mathbf{R}^{\mathbf{2}} \\
\text { Ajustado }\end{array}$ & $\begin{array}{c}\text { Erro } \\
\text { Padrão } \\
\text { Estimado }\end{array}$ & $\begin{array}{c}\text { Durbin- } \\
\text { Watson }\end{array}$ & $\boldsymbol{F}$ & Sig. \\
\hline \hline \multirow{2}{*}{2007} & Maiores & 0,234 & 0,055 & $-0,017$ & 20,185 & 1,717 & 0,764 & 0,619 \\
\cline { 2 - 10 } & Menores & 0,566 & 0,320 & 0,268 & 24,221 & 1,930 & 6,184 & 0,000 \\
\hline \multirow{2}{*}{2008} & Maiores & 0,418 & 0,175 & 0,112 & 15,242 & 1,997 & 2,782 & 0,011 \\
\cline { 2 - 10 } & Menores & 0,480 & 0,230 & 0,172 & 25,516 & 1,696 & 3,934 & 0,001 \\
\hline \multirow{2}{*}{2009} & Maiores & 0,538 & 0,290 & 0,236 & 15,308 & 1,639 & 5,366 & 0,000 \\
\cline { 2 - 9 } & Menores & 0,525 & 0,276 & 0,221 & 24,874 & 1,918 & 5,011 & 0,000 \\
\hline \multirow{2}{*}{2010} & Maiores & 0,329 & 0,108 & 0,040 & 15,284 & 1,583 & 1,596 & 0,147 \\
\cline { 2 - 9 } & Menores & 0,403 & 0,162 & 0,099 & 25,282 & 2,107 & 2,550 & 0,019 \\
\hline \multirow{2}{*}{2012} & Maiores & 0,217 & 0,047 & $-0,026$ & 17,144 & 1,809 & 0,648 & 0,715 \\
\cline { 2 - 9 } & Menores & 0,485 & 0,235 & 0,177 & 24,116 & 2,040 & 4,039 & 0,001 \\
\cline { 2 - 9 } & Maiores & 0,223 & 0,050 & $-0,023$ & 16,470 & 1,621 & 0,688 & 0,682 \\
\hline \multirow{2}{*}{2013} & Menores & 0,460 & 0,212 & 0,152 & 24,136 & 1,970 & 3,537 & 0,002 \\
\cline { 2 - 9 } & Menores & 0,286 & 0,082 & 0,012 & 17,821 & 1,947 & 1,174 & 0,325 \\
\hline \hline \multirow{2}{*}{2014} & Maiores & 0,486 & 0,236 & 0,178 & 24,091 & 2,183 & 4,061 & 0,001 \\
\cline { 2 - 9 } & Menores & 0,557 & 0,092 & 0,022 & 19,165 & 1,892 & 1,324 & 0,248 \\
\hline \hline
\end{tabular}

Preditores: Liquidez geral, Liquidez corrente, Crescimento, Ativo total, Patrimônio líquido, ROA, ROE e Taxa SELIC. Variável dependente: Composição do Endividamento.

Fonte: Dados da pesquisa.

Expresso pelo $\mathrm{R}^{2}$, o coeficiente de Pearson representa a capacidade explicativa do modelo e de acordo com Fávero et al. (2009), o R ${ }^{2}$ pode variar entre 0 e 1 (0 e 100\%), sendo que quanto mais próximo de 0 as variáveis independentes não serão coerentes para explicar o comportamento da variável dependente em relação às independentes e quanto maior o $\mathrm{R}^{2}$, mais confiáveis serão os valores da regressão.

Observou-se que nos períodos de 2007 e 2014 os maiores coeficientes de $\mathrm{R}^{2}$ foram apresentados pelas menores empresas listadas na BM\&FBovespa com 0,320 e 0,310 respectivamente, o que demonstra alto poder explicativo dessas variáveis independentes em relação à dependente nestes dois períodos. Já o menor poder explicativo foi identificado para as 
maiores empresas no ano de 2011 com coeficiente $R^{2}$ de 0,047, porém não inviabiliza a análise pois o valor apresentado é superior a zero.

Observou-se na Tabela 2, que os valores dos testes de Durbin-Watson demonstram resultados favoráveis pois estão próximos a 2 conforme sugerem Fávero et al. (2009). Nestes casos não ocorreriam problemas com a correlação entre as variáveis. Os valores desse teste permaneceram entre 1,583 e 2,183, o que representa condições favoráveis para permanecer na regressão.

Para constatar significância das variáveis nos períodos, verificou-se o valor de Sig. Para Fávero et al. (2009), para que se constate significância entre as variáveis independentes e a variável dependente, os valores devem igual ou inferior a 0,05. Observa-se que com exceção dos períodos de 2008 e 2009, em que tanto as maiores quanto as menores empresas apresentaram coeficientes de significância favoráveis, os demais períodos só apresentaram significância para as menores empresas.

Na Tabela 3 serão demonstrados os coeficientes de regressão para a variável dependente "composição do endividamento" e as variáveis independentes. Analisando o teste VIF, constatouse que as variáveis analisadas não indicaram multicolinearidade ou apresentam valores aceitáveis.

Tabela 3 - Coeficiente de regressão entre a Composição do Endividamento e as variáveis independentes no período de 2007 a 2014 das maiores empresas

\begin{tabular}{|c|c|c|c|c|c|c|c|c|}
\hline \multirow{2}{*}{ Ano } & \multirow{2}{*}{ Modelo } & \multicolumn{2}{|c|}{$\begin{array}{c}\text { Coeficientes Não } \\
\text { Normalizados } \\
\end{array}$} & \multirow{2}{*}{$\begin{array}{c}\text { Coeficientes } \\
\text { Normalizados } \\
\text { Beta }\end{array}$} & \multirow{2}{*}{$\mathbf{T}$} & \multirow{2}{*}{ Sig. } & \multicolumn{2}{|c|}{$\begin{array}{c}\text { Colinearidade } \\
\text { Estatística }\end{array}$} \\
\hline & & B & $\begin{array}{l}\text { Std. } \\
\text { Error }\end{array}$ & & & & Tolerância & VIF \\
\hline 2007 & (Constant) & 40,486 & 4,451 & & 0,096 & 0,000 & & \\
\hline \multirow{4}{*}{2008} & (Constant) & 39,513 & 3,606 & & 10,957 & 0,000 & & \\
\hline & ROA & 0,543 & 0,177 & 0,311 & 3,081 & 0,003 & 0,883 & 1,133 \\
\hline & Ativo Total & $-8,968 \mathrm{E}-8$ & 0,000 & $-0,204$ & $-1,914$ & 0,059 & 0,786 & 1,272 \\
\hline & ROE & 0,040 & 0,018 & 0,219 & 2,187 & 0,031 & 0,898 & 1,113 \\
\hline \multirow{6}{*}{2009} & (Constant) & 40,341 & 3,332 & & 12,107 & 0,000 & & \\
\hline & Liquidez Geral & 4,070 & 1,214 & 0,349 & 3,353 & 0,001 & 0,712 & 1,404 \\
\hline & Liquidez Corrente & $-4,011$ & 1,237 & $-0,335$ & $-3,242$ & 0,002 & 0,722 & 1,386 \\
\hline & Ativo Total & $-3,238 \mathrm{E}-7$ & 0,000 & $-0,747$ & $-3,464$ & 0,001 & 0,166 & 6,031 \\
\hline & Patrimônio Líquido & $1,423 \mathrm{E}-7$ & 0,000 & 0,333 & 3,240 & 0,002 & 0,731 & 1,368 \\
\hline & Crescimento & $6,944 \mathrm{E}-7$ & 0,000 & 0,710 & 3,102 & 0,03 & 0,147 & 6,793 \\
\hline \multirow{2}{*}{2010} & (Constant) & 35,632 & 4,398 & & 8,101 & 0,000 & & \\
\hline & Ativo Total & $-1,128 \mathrm{E}-7$ & 0,000 & $-0,413$ & $-2,064$ & 0,042 & 0,242 & 4,129 \\
\hline 2011 & (Constant) & 41,180 & 5,054 & & 8,148 & 0,000 & & \\
\hline 2012 & (Constant) & 35,925 & 5,130 & & 7,002 & 0,000 & & \\
\hline \multirow{2}{*}{2013} & (Constant) & 32,387 & 5,170 & & 6,264 & & & \\
\hline & Liquidez Corrente & $-1,152$ & 0,517 & $-0,247$ & $-2,229$ & 0,028 & 0,816 & 1,226 \\
\hline 2014 & (Constant) & 38,115 & 5,091 & & 8,487 & 0,000 & & \\
\hline
\end{tabular}

Variável dependente: Composição do endividamento.

Fonte: Dados da pesquisa.

Observou-se que as variáveis ROA, ativo total e ROE significante em 2008, Liquidez geral, Liquidez corrente, Ativo total, Patrimônio líquido e Crescimento significante em 2009, ativo total 
significante em 2010 e liquidez corrente significante em 2013 explicam a composição do endividamento das maiores empresas listadas na BM\&FBovespa com significância igual ou inferior a 0,05. Tais resultados corroboram os estudos de Fank, Angonese e Toledo Filho (2010) e Tristão e Dutra (2012) que encontraram significância entre o endividamento e os índices de rentabilidade - ROA e ROE.

Quanto ao crescimento, Nakamura, Martin e Kimura (2004) encontraram correlação entre o nível de crescimento das empresas e seu nível de endividamento. A correlação entre o tamanho da empresa e o endividamento foram demonstrados nas pesquisas de Laureano (2008), Tristão e Dutra (2012) e Angonese, Santos e Lavarda (2010). Todavia, o resultado de significância do tamanho da empresa apresentado na Tabela 2 divergiu do resultado obtido por Fank, Angonese e Toledo Filho (2010), que não encontraram relação significativa entre o tamanho da empresa e o endividamento.

Pode-se observar que as maiores empresas nos mandatos Lula (2007-2010) e parte do mandato Dilma (2011-2013) encontravam-se menos financiadas com recursos de terceiros. Para Mamede et al. (2017) empresas estatais conseguiam melhores taxas de juros do que empresas privadas, o que facilitava o financiamento e melhores condições de amortização.

Quando os recursos são captados em banco de desenvolvimento, que possuíam participação governamental, a desconfiança pelo risco de crédito seria maior nas empresas privadas que na estatal. Os autores afirmam ainda, que o governo não cobraria maiores taxas de juros de empresas estatais, pois geraria desconfiança no mercado, dessa forma, repassava este custo para as empresas privadas, com a finalidade de compensação de resultados.

Nos anos de 2007, 2011, 2012 e 2014, nenhuma das variáveis analisadas apresentou relação de significância. As variáveis independentes mencionadas na metodologia de pesquisa que não apresentaram significância, não foram apresentadas nas tabelas de análise. Na Tabela 4 é possível verificar os coeficientes de regressão envolvendo as 100 menores empresas analisadas.

Tabela 4 - Coeficiente de regressão entre a Composição do Endividamento e as variáveis independentes no período de 2007 a 2014 das menores empresas

\begin{tabular}{|c|c|c|c|c|c|c|c|c|}
\hline \multirow[t]{2}{*}{ Ano } & \multirow[t]{2}{*}{ Modelo } & \multicolumn{2}{|c|}{$\begin{array}{c}\text { Coeficientes Não } \\
\text { Normalizados }\end{array}$} & \multirow{2}{*}{$\begin{array}{c}\begin{array}{c}\text { Coeficientes } \\
\text { Normalizados }\end{array} \\
\text { Beta }\end{array}$} & \multirow[t]{2}{*}{$\mathbf{T}$} & \multirow[t]{2}{*}{ Sig. } & \multicolumn{2}{|c|}{$\begin{array}{c}\text { Colinearidade } \\
\text { Estatística }\end{array}$} \\
\hline & & B & Std. Error & & & & Tolerância & VIF \\
\hline \multirow{3}{*}{2007} & (Constant) & 44,064 & 3,965 & & 11,114 & 0,000 & & \\
\hline & Liquidez Geral & 3,405 & 0,976 & 0,608 & 3,490 & 0,001 & 0,244 & 4,103 \\
\hline & Liquidez Corrente & $-1,922$ & 0,660 & $-0,495$ & $-2,913$ & 0,004 & 0,256 & 3,910 \\
\hline \multirow{3}{*}{2008} & (Constant) & 41,614 & 4,336 & & 9,597 & 0,000 & & \\
\hline & Liquidez Geral & 1,818 & 0,766 & 0,378 & 2,374 & 0,020 & 0,330 & 3,032 \\
\hline & Liquidez Corrente & $-0,974$ & 0,447 & $-0,340$ & $-2,177$ & 0,032 & 0,343 & 2,912 \\
\hline \multirow{4}{*}{2009} & (Constant) & 44,129 & 4,378 & & 10,080 & 0,000 & & \\
\hline & Liquidez Geral & 2,035 & 0,905 & 0,271 & 2,250 & 0,027 & 0,544 & 1,840 \\
\hline & Liquidez Corrente & $-1,580$ & 0,810 & $-0,227$ & $-1,951$ & 0,054 & 0,579 & 1,726 \\
\hline & Patrimônio Líquido & $6,351 \mathrm{E}-5$ & 0,000 & 0,818 & 3,477 & 0,001 & 0,142 & 7,024 \\
\hline \multirow{4}{*}{2010} & (Constant) & 39,014 & 4,770 & & 8,179 & 0,000 & & \\
\hline & Liquidez Geral & 2,829 & 1,133 & 0,329 & 2,497 & 0,014 & 0,523 & 1,912 \\
\hline & Liquidez Corrente & $-1,860$ & 0,922 & $-0,265$ & $-2,016$ & 0,047 & 0,528 & 1,894 \\
\hline & Patrimônio Líquido & 1,649E-5 & 0,000 & 0,247 & 2,142 & 0,035 & 0,686 & 1,457 \\
\hline \multirow{3}{*}{2011} & (Constant) & 39,342 & 4,520 & & 8,704 & 0,000 & & \\
\hline & Liquidez Geral & 2,649 & 0,971 & 0,273 & 2,728 & 0,008 & 0,833 & 1,200 \\
\hline & Liquidez Corrente & $-0,802$ & 0,272 & $-0,290$ & $-2,949$ & 0,004 & 0,860 & 1,162 \\
\hline
\end{tabular}


Dallabona, L. F., Gonçalves, M., \& Radloff, G. R.

\begin{tabular}{|c|c|c|c|c|c|c|c|c|}
\hline & Patrimônio Líquido & $1,684 \mathrm{E}-5$ & 0,000 & 0,283 & 2,727 & 0,008 & 0,773 & 1,293 \\
\hline \multirow{4}{*}{2012} & (Constant) & 40,100 & 4,578 & & 8,759 & 0,000 & & \\
\hline & Liquidez Geral & 2,323 & 0,966 & 0,287 & 2,405 & 0,018 & 0,602 & 1,660 \\
\hline & Liquidez Corrente & $-1,804$ & 0,619 & $-0,350$ & $-2,915$ & 0,004 & 0,593 & 1,686 \\
\hline & Patrimônio Líquido & $1,265 \mathrm{E}-5$ & 0,000 & 0,240 & 2,299 & 0,024 & 0,784 & 1,275 \\
\hline \multirow{3}{*}{2013} & (Constant) & 40,779 & 4,577 & & 8,909 & 0,000 & & \\
\hline & Liquidez Geral & 2,733 & 0,954 & 0,321 & 2,865 & 0,005 & 0,661 & 1,512 \\
\hline & Liquidez Corrente & $-1,904$ & 0,564 & $-0,376$ & $-3,374$ & 0,001 & 0,668 & 1,498 \\
\hline \multirow{6}{*}{2014} & (Constant) & 41,488 & 3,764 & & 11,022 & 0,000 & & \\
\hline & Liquidez Geral & 2,486 & 0,720 & 0,329 & 3,455 & 0,001 & 0,824 & 1,213 \\
\hline & Liquidez Corrente & $-1,701$ & 0,453 & $-0,355$ & $-3,754$ & 0,000 & 0,837 & 1,194 \\
\hline & Patrimônio Líquido & 7,812E-6 & 0,000 & 0,195 & 2,101 & 0,038 & 0,867 & 1,153 \\
\hline & ROE & 0,177 & 0,071 & 0,219 & 2,508 & 0,014 & 0,983 & 1,017 \\
\hline & ROA & $-0,005$ & 0,002 & $-0,201$ & $-2,311$ & 0,023 & 0,987 & 1,013 \\
\hline
\end{tabular}

Variável dependente: Composição do endividamento.

Fonte: Dados da pesquisa.

Dentre as 100 menores empresas, todos os anos possuíram alguma variável que obteve significância em relação à variável dependente. A liquidez geral e a liquidez corrente explicaram os valores de composição de endividamento em todos os anos analisados, demonstrando solidez no pagamento de suas dívidas para as empresas analisadas.

Este resultado corrobora os dados de Laureano (2008), que encontrou em sua pesquisa que a liquidez no curto prazo se mostrou significantemente correlacionada, fortalecendo a ideia de que as empresas mais líquidas são as que mais adotam as posições menos endividadas no curto prazo.

A variável patrimônio líquido também apresentou significância nos anos de 2009 até 2012 e em 2014 demonstrando neste período um coeficiente de 0,03. Uma das partes do patrimônio líquido é formada por reservas de lucros, Espínola e Kayo (2013) alegam que a lucratividade das empresas foi importante para determinar o endividamento das empresas no período da crise financeira global. Laureano (2008) também encontrou significância, afirmando que as empresas preferem se financiar por meio de seus lucros retidos. Porém, quanto mais lucrativa é a empresa, menor é o seu endividamento.

As variáveis ROE e ROA apresentaram significância no ano de 2014, com coeficientes de 0,01 e 0,02 respectivamente, o que leva ao entendimento de que, nesse ano, as empresas tiveram retorno sobre seus investimentos tanto sobre o patrimônio líquido quanto seus ativos. Estes resultados corroboram as evidencias encontradas por Nakamura, Martin e Kimura (2004), Bastos e Nakamura (2009), de que os índices de rentabilidade explicam os níveis de endividamento.

Já estes resultados divergem do estudo de Jorge e Armada (2001) em que os níveis de rentabilidade não representaram ser determinantes do endividamento. Cabe salientar que essa divergência pode ser originada no período em que foi realizada a pesquisa (1990-1995) e o país investigado (Portugal). As demais variáveis não apresentaram significância para explicar a composição do endividamento.

As evidências obtidas demonstram que, em ambos períodos presidenciais, as 100 menores empresas não captaram tantos recursos com credores externos. A “boa" liquidez e a capacidade de retorno das organizações mostra que as mesmas conseguiram financiar suas atividades com recursos próprios, pois sua liquidez no pagamento de suas obrigações e as altas taxas de juros bancários, as fizeram atuar com seus próprios recursos, se apresentando menos financiadas nos dois mandatos. 
Quando analisaram a pós crise, Rosa e Costa (2014) concluíram que a liquidez das empresas no período de 2007 a 2009 se mantiveram constantes, ou seja, as empresas estavam pagando suas dívidas, porém a rentabilidade dos negócios diminuíram na época.

A significância das variáveis ROA e ROE no ano de 2014 demonstra que no segundo mandato analisado, o Governo Dilma proporcionou aos investidores melhores retornos sobre o investimento realizado.

Enquanto a composição do endividamento procura demonstrar a política de captação de recursos dentro das organizações, o endividamento geral mede a proporção de ativos que é financiado por terceiros. Assim, é possível observar na Tabela 5 a correlação entre o endividamento geral das 100 maiores e 100 menores utilizando as mesmas variáveis independentes.

Tabela 5 - Correlação entre as variáveis independentes das maiores e menores empresas

\begin{tabular}{|c|c|c|c|c|c|c|c|c|}
\hline Ano & Empresas & $\mathbf{R}$ & $\mathbf{R}^{2}$ & $\begin{array}{c}R^{2} \\
\text { Ajustado }\end{array}$ & $\begin{array}{c}\text { Erro } \\
\text { Padrão } \\
\text { Estimado } \\
\end{array}$ & $\begin{array}{l}\text { Durbin- } \\
\text { Watson }\end{array}$ & $F$ & Sig. \\
\hline \multirow{2}{*}{2007} & Maiores & 0,641 & 0,411 & 0,366 & 31,770 & 1,561 & 9,176 & 0,000 \\
\hline & Menores & 0,957 & 0,916 & 0,910 & 480,524 & 2,031 & 143,373 & 0,000 \\
\hline \multirow{2}{*}{2008} & Maiores & 0,502 & 0,252 & 0,195 & 32,395 & 1,590 & 4,428 & 0,000 \\
\hline & Menores & 0,990 & 0,981 & 0,979 & 521,665 & 1,846 & 664,468 & 0,000 \\
\hline \multirow{2}{*}{2009} & Maiores & 0,639 & 0,408 & 0,363 & 20,750 & 1,718 & 9,073 & 0,000 \\
\hline & Menores & 0,993 & 0,986 & 0,985 & 607,466 & 2,200 & 949,331 & 0,000 \\
\hline \multirow{2}{*}{2010} & Maiores & 0,646 & 0,417 & 0,373 & 20,871 & 1,663 & 9,405 & 0,000 \\
\hline & Menores & 0,790 & 0,625 & 0,596 & 826,661 & 2,103 & 21,872 & 0,000 \\
\hline \multirow{2}{*}{2011} & Maiores & 0716 & 0,513 & 0,476 & 15,909 & 1,790 & 13,829 & 0,000 \\
\hline & Menores & 0,931 & 0,867 & 0,857 & 590,118 & 2,075 & 85,562 & 0,000 \\
\hline \multirow{2}{*}{2012} & Maiores & 0,894 & 0,799 & 0,783 & 25,030 & 2,353 & 52,173 & 0,000 \\
\hline & Menores & 0,886 & 0,785 & 0,768 & 747,828 & 1,967 & 47,856 & 0,000 \\
\hline \multirow{2}{*}{2013} & Maiores & 0,535 & 0,286 & 0,231 & 47,797 & 2,040 & 5,259 & 0,000 \\
\hline & Menores & 0,866 & 0,750 & 0,731 & 1110,567 & 2,036 & 39,407 & 0,000 \\
\hline \multirow{2}{*}{2014} & Maiores & 0,779 & 0,607 & 0,577 & 33,528 & 1,635 & 20,314 & 0,000 \\
\hline & Menores & 0,989 & 0,978 & 0,976 & 2476,404 & 1,981 & 582,584 & 0,000 \\
\hline
\end{tabular}

Preditores: Liquidez geral, Liquidez corrente, Crescimento, Ativo total, Patrimônio líquido, ROA, ROE e Taxa SELIC. Variável dependente: Endividamento Geral.

Fonte: Dados da pesquisa.

O R ${ }^{2}$ das 100 maiores empresas foi respectivamente 41,1\%, 25,2\%, 40,8\%, 41,7\%, 51,3\%, $79,9 \%, 28,6 \%, 60,7 \%$. Diante dos resultados das regressões lineares múltiplas apresentados na Tabela 4, o coeficiente de determinação $\left(R^{2}\right)$ teve maior poder explicativo no ano de 2012 , sendo que $79,9 \%$ da variação do endividamento geral das maiores empresas foi explicada pelo conjunto de variáveis compostas no modelo.

Porém, mais expressivos foram os resultados do $\mathrm{R}^{2}$ dos anos analisados em relação às 100 menores empresas, apresentando valores entre 60,7\% e 98,1\%, demonstrando assim um alto poder explicativo. Os índices de Sig. da correlação das variáveis independentes com a variável endividamento geral apresentou valor inferior a 0,05 em todos os anos.

Este resultado evidenciou que todos os coeficientes de significância foram totalmente favoráveis. Também na Tabela 4 observou-se que os valores de Durbin-Watson apresentaram 
valores entre 1,561 a 2,353, podendo permanecer na regressão em condições favoráveis, por que se encontram próximos a 2.

Na Tabela 6 são demonstrados os coeficientes de regressão envolvendo a variável dependente "Endividamento geral" e as demais variáveis independentes entre as 100 maiores empresas. Segundo o resultado pelo teste de multicolinearidade, verificou-se que exceto a variável ROE do ano de 2011, que não representou multicolinearidade, os demais resultados apresentaram valores de 2 a 10, considerados aceitáveis.

A variável Liquidez geral apresentou significância em todos os períodos analisados demonstrando mais uma vez a solidez das empresas no ano. As variáveis ROA e ROE também apresentaram significância nos períodos de 2007 (ROA), 2009 (ROA, ROE), 2010 (ROA), 2011 (ROE), 2012 (ROA) e 2014 (ROA), apresentando índices entre 0,000 e 0,031. Entendeu-se que houve grande rentabilidade dos recursos aplicados e eficiência na utilização do capital investido.

Tabela 6 - Coeficiente de regressão entre o Endividamento Geral e as variáveis independentes no período de 2007 a 2014 das maiores empresas

\begin{tabular}{|c|c|c|c|c|c|c|c|c|}
\hline \multirow{2}{*}{ Ano } & \multirow{2}{*}{ Modelo } & \multicolumn{2}{|c|}{$\begin{array}{c}\text { Coeficientes Não } \\
\text { Normalizados }\end{array}$} & \multirow{2}{*}{$\begin{array}{c}\begin{array}{c}\text { Coeficientes } \\
\text { Normalizados }\end{array} \\
\text { Beta }\end{array}$} & \multirow{2}{*}{$\mathbf{T}$} & \multirow{2}{*}{ Sig. } & \multicolumn{2}{|c|}{$\begin{array}{c}\text { Colinearidade } \\
\text { Estatística }\end{array}$} \\
\hline & & B & $\begin{array}{l}\text { Std. } \\
\text { Error }\end{array}$ & & & & Tolerância & VIF \\
\hline \multirow{4}{*}{2007} & (Constant) & 67,182 & 7,005 & & 9,590 & 0,000 & & \\
\hline & Liquidez Geral & $-5,096$ & 1,837 & $-0,273$ & $-2,774$ & 0,007 & 0,662 & 1,1512 \\
\hline & $\mathrm{ROA}$ & 2,312 & 0,427 & 0,499 & 5,418 & 0,000 & 0,754 & 1,327 \\
\hline & Patrimônio Líquido & $-3,89 \mathrm{E}-7$ & 0,000 & $-0,033$ & $-0,163$ & 0,871 & 0,152 & 6,598 \\
\hline \multirow{2}{*}{2008} & (Constant) & 97,235 & 7,664 & & 12,687 & 0,000 & & \\
\hline & Liquidez Geral & $-11,05$ & 2,669 & $-0,409$ & $-4,142$ & 0,000 & 0,833 & 1,200 \\
\hline \multirow{4}{*}{2009} & (Constant) & 82,611 & 4,516 & & 18,291 & 0,000 & & \\
\hline & Liquidez Geral & $-9,173$ & 1,646 & $-0,530$ & $-5,575$ & 0,000 & 0,712 & 1,404 \\
\hline & $\mathrm{ROA}$ & 0,836 & 0,340 & 0,225 & 2,454 & 0,016 & 0,767 & 1,304 \\
\hline & ROE & $-0,255$ & 0,109 & $-0,216$ & $-2,350$ & 0,021 & 0,761 & 1,314 \\
\hline \multirow{3}{*}{2010} & (Constant) & 86,317 & 6,006 & & 14,371 & 0,000 & & \\
\hline & Liquidez Geral & $-13,08$ & 2,095 & $-0,524$ & $-6,249$ & 0,000 & 0,902 & 1,109 \\
\hline & ROA & 0,922 & 0,332 & 0,249 & 2,780 & 0,007 & 0,787 & 1,270 \\
\hline \multirow{3}{*}{2011} & (Constant) & 98,540 & 4,690 & & 21,011 & 0,000 & & \\
\hline & Liquidez Geral & $-17,17$ & 2,047 & $-0,640$ & $-8,389$ & 0,000 & 0,910 & 1,099 \\
\hline & $\mathrm{ROE}$ & $-0,129$ & 0,059 & $-0,172$ & $-2,191$ & 0,031 & 0,857 & 0,857 \\
\hline \multirow{3}{*}{2012} & (Constant) & 107,33 & 7,797 & & 13,767 & 0,000 & & \\
\hline & Liquidez Geral & $-21,82$ & 4,186 & $-0,267$ & $-5,213$ & 0,000 & 0,831 & 1,204 \\
\hline & $\mathrm{ROA}$ & $-2,010$ & 0,128 & $-0,776$ & $-15,660$ & 0,000 & 0,891 & 1,122 \\
\hline \multirow{2}{*}{2013} & $($ Constant $)$ & 137,586 & 13,865 & & 9,923 & 0,000 & & \\
\hline & Liquidez Geral & $-41,533$ & 7,635 & $-0,533$ & $-5,440$ & 0,000 & 0,810 & 1,235 \\
\hline \multirow{4}{*}{2014} & (Constant) & 121,068 & 8,905 & & 13,595 & 0,000 & & \\
\hline & Liquidez Geral & $-26,356$ & 5,168 & $-0,411$ & $-5,100$ & 0,000 & 0,657 & 1,521 \\
\hline & $\mathrm{ROA}$ & $-2,218$ & 0,285 & $-0,606$ & $-7,770$ & 0,000 & 0,702 & 1,424 \\
\hline & Ativo Total & $-1,529 \mathrm{e}-7$ & 0,000 & $-0,254$ & $-2,046$ & 0,044 & 0,277 & 3,609 \\
\hline
\end{tabular}

Variável dependente: Endividamento Geral.

Fonte: Dados da pesquisa. 
Estes resultados convergem aos estudos de Fank, Angonese e Toledo Filho (2010) que demonstraram que houve relação de significância entre a rentabilidade e o nível de endividamento das empresas. Além destes autores, Bastos e Nakamura (2009), em sua pesquisa com os países Brasil, México e Chile, encontraram relação de significância entre o nível de endividamento e o índice ROA, corroborando os resultados da Tabela 5.

A Tabela 7 apresenta o coeficiente de regressão entre o "Endividamento geral" e as variáveis independentes das menores empresas. Analisou-se também o teste de multicolinearidade VIF no qual os valores estabeleceram-se entre 1,013 e 6,124. Estes valores, como se encaixaram entre 2 e 10, são considerados valores aceitáveis.

Observando os dados gerados pela regressão para as 100 menores empresas, a variável que apresenta significância em todos os mandados presidenciais é a variável ROA demonstrando a eficiência dos gestores no uso do capital investido nas organizações. Deste modo, observou-se que quanto maior foi a rentabilidade da empresa, menor foi a captação de recursos de terceiros para operacionalização de fluxo de caixa.

Tabela 7 - Coeficiente de regressão entre o Endividamento Geral e as variáveis independentes no período de 2007 a 2014 das menores empresas

\begin{tabular}{|c|c|c|c|c|c|c|c|c|}
\hline \multirow{2}{*}{ Ano } & \multirow{2}{*}{ Modelo } & \multicolumn{2}{|c|}{$\begin{array}{c}\text { Coeficientes Não } \\
\text { Normalizados } \\
\end{array}$} & \multirow{2}{*}{$\begin{array}{c}\begin{array}{c}\text { Coeficientes } \\
\text { Normalizados }\end{array} \\
\text { Beta }\end{array}$} & \multirow{2}{*}{$\mathbf{T}$} & \multirow{2}{*}{ Sig. } & \multicolumn{2}{|c|}{$\begin{array}{c}\text { Colinearidade } \\
\text { Estatística }\end{array}$} \\
\hline & & B & $\begin{array}{l}\text { Std. } \\
\text { Error }\end{array}$ & & & & Tolerância & VIF \\
\hline \multirow{4}{*}{2007} & (Constant) & 245,275 & 78,654 & & 3,118 & 0,002 & & \\
\hline & Ativo Total & $-0,001$ & 0,000 & $-0,102$ & $-2,978$ & 0,004 & 0,771 & 1,298 \\
\hline & ROA & $-11,200$ & 0,645 & $-1,178$ & $-17,362$ & 0,000 & 0,198 & 5,042 \\
\hline & Patrimônio Líquido & 0,002 & 0,000 & 0,288 & 3,882 & 0,000 & 0,166 & 6,025 \\
\hline \multirow{3}{*}{2008} & (Constant) & 148,498 & 88,651 & & 1,675 & 0,097 & & \\
\hline & $\mathrm{ROA}$ & $-9,506$ & 0,309 & $-1,052$ & $-30,803$ & 0,000 & 0,181 & 5,531 \\
\hline & Patrimônio Líquido & 0,001 & 0,000 & 0,075 & 2,073 & 0,041 & 0,160 & 6,261 \\
\hline \multirow{2}{*}{2009} & (Constant) & 208,791 & 106,918 & & 1,953 & 0,054 & & \\
\hline & ROA & $-10,175$ & 0,322 & $-0,953$ & $-31,612$ & 0,000 & 0,163 & 6,124 \\
\hline \multirow{3}{*}{2010} & (Constant) & $-16,725$ & 155,967 & & $-0,107$ & 0,915 & & \\
\hline & $\mathrm{ROA}$ & $-17,169$ & 1,522 & $-0,877$ & $-11,281$ & 0,000 & 0,675 & 1,481 \\
\hline & Patrimônio Líquido & 0,001 & 0,000 & 0,185 & 2,396 & 0,019 & 0,686 & 1,457 \\
\hline \multirow{3}{*}{2011} & (Constant) & $-90,064$ & 110,608 & & $-0,814$ & 0,418 & & \\
\hline & ROA & $-19,608$ & 0,851 & $-1,004$ & $-23,039$ & 0,000 & 0,763 & 1,311 \\
\hline & Patrimônio Líquido & 0,001 & 0,000 & 0,177 & 4,098 & 0,000 & 0,773 & 1,293 \\
\hline \multirow{3}{*}{2012} & (Constant) & 43,903 & 141,850 & & 0,309 & 0,758 & & \\
\hline & ROA & $-13,267$ & 0,797 & $-0,973$ & $-16,652$ & 0,000 & 0,686 & 1,457 \\
\hline & ROE & 2,112 & 0,324 & 0,335 & 6,512 & 0,000 & 0,883 & 1,133 \\
\hline \multirow{3}{*}{2013} & (Constant) & $-70,047$ & 210,986 & & $-0,332$ & 0,741 & & \\
\hline & $\mathrm{ROA}$ & $-14,987$ & 0,978 & $-0,916$ & $-15,329$ & 0,000 & 0,761 & 1,314 \\
\hline & Patrimônio Líquido & 0,000 & 0,000 & 0,118 & 2,015 & 0,047 & 0,798 & 1,253 \\
\hline \multirow{2}{*}{2014} & (Constant) & 726,249 & 400,171 & & 1,815 & 0,073 & & \\
\hline & ROA & $-15,712$ & 0,248 & $-0,988$ & $-63,344$ & 0,000 & 0,987 & 1,013 \\
\hline
\end{tabular}

Variável dependente: Endividamento Geral.

Fonte: Dados da pesquisa. 
Estes resultados também foram encontrados na pesquisa de Bastos e Nakamura (2013). Assim, quanto maior foi a rentabilidade da empresa, maior foi o caixa operacional, sem recorrer demais ao capital de terceiros. A variável patrimônio líquido também se mostrou significativa à variável dependente nos anos de 2007, 2008, 2010, 2011 e 2013. Esse resultado pôde ser esperado, visto que essa variável representa a riqueza efetiva da empresa, ou seja, se a empresa utiliza de sua riqueza para não se endividar, por seu patrimônio líquido ser significante.

Em ambos os mandatos presidenciais, os investimentos ainda continuaram recebendo retorno sobre seus investimentos, isso pode ser entendido pelo fato de que já que os juros bancários são altos, visando a promoção e crescimento de organizações estatais, as empresas privadas acabaram se alto financiando, melhorando assim seus resultados e distribuição de lucros.

Os resultados apresentados em todas as regressões podem ajudar na definição de quais indicadores mais se destacam em relação ao endividamento. Desta forma, pode-se definir um parâmetro a ser utilizado para a gestão quando "o assunto" for endividamento.

\section{CONSIDERAÇÕES FINAIS}

O estudo objetivou analisar quais variáveis econômico-financeiras explicam a composição e o endividamento das cem maiores e menores empresas listadas na BM\&FBovespa nos últimos dois mandatos presidenciais.

Os resultados apresentaram que houve um grupo de variáveis significantes diferentes para cada variável dependente. Não houve um padrão de variáveis independentes que explicasse todas as variáveis dependentes. Também foram diferentes os resultados entre as 100 maiores empresas e as 100 menores empresas. Aplicando-se a mesma regressão, com as mesmas variáveis, obtiveramse relações de significância diferentes entre as 100 maiores e as 100 menores empresas.

A não realização de padrões de variáveis sugerem que há diferenças de abordagens nas maiores e menores empresas. Para Bernardelli e Bernardelli (2016) a crise política instaurada no Brasil, contribuiu de forma significativa para o declínio do desempenho econômico do país. Assim, diferentes tipos empresariais atuaram de formas divergentes ao que se refere suas formas de financiamento. Porém, percebeu-se que por mais que a instabilidade política fosse grande no país, as relações de liquidez tanto nas 100 menores quanto nas 100 maiores empresas foram positivas.

No ano de 2007, as variáveis: ROA, ROE, Ativo total, Patrimônio líquido, Liquidez geral e Liquidez corrente apresentaram significância sobre uma das três variáveis dependentes demonstrando maior solidez e baixo índice de solvência para as empresas analisadas. A variável crescimento apresentou significância em alguma variável dependente apenas nos anos de 2009 e 2011. As variáveis Liquidez geral e Liquidez corrente apresentaram significância em todo período analisado, já a variável ROE não apresentou significância apenas no ano de 2013. Para os demais períodos, o ROE apresentou significância sobre alguma variável dependente em todos os anos, enquanto que a variável ROA apresentou significância em todos os períodos. A variável Patrimônio Líquido também apresentou significância em relação a algumas variáveis dependentes em todos os anos, afirmando que, realmente, as empresas utilizam seus recursos próprios para investir. Diante disso, subentende-se que a instabilidade financeira do país nos anos de 2007 até 2010 (mandato Lula) fez com que as empresas preferissem o uso de recursos próprios ao invés de terceiros.

A variável crescimento só apresentou significância nos períodos de 2009 e 2011, sendo desta forma, a variável que menos explicou o endividamento, depois da taxa Selic, que não apresentou relação de significância em nenhum período.

Tendo em vista a análise sob a holística dos períodos presidenciais, no primeiro período presidencial (2007-2010), verificou-se que a liquidez geral, liquidez corrente, patrimônio líquido, 
ROA, ativo total e crescimento explicam a variável dependente composição do endividamento nas 100 maiores empresas. Ainda analisando a composição do endividamento, verificou-se que no segundo período presidencial (2011-2014), apenas a variável liquidez corrente explica a variável perante as 100 maiores empresas. Concluindo assim que, as 100 maiores empresas, em ambos períodos presidenciais, estavam menos endividadas, pois apresentaram em quase todos os anos liquidez e retornos sobre os investimentos realizados.

Quando a composição do endividamento foi analisada nos dos dois períodos presidenciais para as 100 menores empresas, as determinantes da composição do endividamento foram semelhantes de 2007 a 2010 e de 2011 a 2014 para as 100 menores, mas mudaram quando se trata das 100 maiores, pois quanto maior a empresa é, mais condições de se financiar elas têm.

Enquanto os resultados da regressão entre as 100 maiores empresas resultou na significância de diversas variáveis diferentes, a regressão da mesma variável dependente para com as 100 menores empresas resultou em um padrão de significância das variáveis liquidez geral, liquidez corrente e patrimônio líquido. Esses resultados demonstraram que não há um padrão de explicação do endividamento independentemente pelo tamanho das empresas. Variáveis que explicam o endividamento das maiores não são os mesmos que explicam o endividamento das menores, o que revelou cenários diferentes de endividamento para as empresas durante o mesmo período econômico. Foi possível perceber um padrão de maioria de significância da rentabilidade do ativo (ROA) com a variável dependente endividamento geral tanto das 100 maiores empresas, quanto das 100 menores empresas.

A variável menos expressiva em sua significância foi a variável crescimento, explicando o nível de endividamento apenas para a amostra das 100 maiores empresas em 2009, na regressão com a composição do endividamento como variável dependente. Frente as 100 menores empresas, a variável não apresentou significância em nenhum período. De todas as variáveis independentes selecionadas para os cálculos, a única variável que não explicou nenhuma das variáveis dependentes foi a taxa SELIC, contrapondo o estudo de Laureano (2008) em que quanto maiores os níveis de juros, menores serão os desejos das empresas de se endividar, encontrando relação entre os níveis de endividamento e a taxa SELIC.

Perante as diferentes maneiras de calcular o nível de endividamento das empresas, independentemente do seu porte, os valores de liquidez e os valores de rentabilidade estão intimamente ligados aos valores do endividamento das empresas. Observa-se isso na forma em que as variáveis liquidez geral, liquidez corrente, rentabilidade do ativo e rentabilidade do patrimônio líquido apareceram frequentemente entre os resultados das regressões. Desta forma, é necessário não somente controlar os resultados contábeis de endividamento, mas também os de liquidez e de rentabilidade, uma vez que eles estão interligados.

Cabe destacar que, no primeiro mandato Lula (2007-2010), as ações governamentais focaram no crescimento e manutenção de organizações que realizaram atividades públicas, com isso, as taxas de juros foram elevadas para organizações de caráter privado, provocando assim uma diminuição na captação de recursos de terceiros e maior uso de recursos próprios.

No segundo período estudado, mandato Dilma (2011-2014), notou-se uma melhora por parte das 100 maiores empresas, principalmente quando o endividamento geral foi analisado, em que os índices apresentaram "uma piora". Pode-se entender que para empresas menores, a capacidade de financiamento é mais difícil.

Ambos os grupos de empresas se mostraram muito mais líquidas no primeiro mandato presidencial Lula entre os anos de 2007 a 2010. Pode-se concluir que por menos endividadas elas estivessem, as empresas se mantiveram estáveis. Esse fator pode ser compreendido então que, de alguma maneira, a crise econômica de 2008 impactou, de alguma maneira, as empresas brasileiras. 
Embora esta pesquisa tenha alcançado alguns resultados semelhantes àqueles obtidos por autores de estudos anteriores e em outros momentos, apresentou resultados divergentes, acreditase que fatores involuntários como os diferentes períodos estudados, amostras de diferentes países, conjuntura do cenário econômico das amostras tenham exercido interação. Desta forma, sugere-se novos estudos acerca de determinantes de endividamento, pois trata-se de um assunto altamente relevante para a continuidade das empresas.

Para estudos futuros, sugere-se a investigação em outros setores específicos da economia, pois cada setor pode ser influenciado por diferentes forças externas, alterando assim o padrão de endividamento. Sugere-se, também, ampliar o estudo, comparando tais dados com economias de outros países e com os resultados econômicos desses países. Essa análise pode demonstrar resultados positivos que podem, inclusive, ser adotado por empresas brasileiras.

\section{REFERÊNCIAS}

Acioly, L. et al. (2009). Desdobramentos de curto e médio prazo da crise atual. Texto para discussão n. 1441. Rio de Janeiro: IPEA.

Angonese, R., Santos, P. S. A. \& Lavarda, C. E. F. (2010). Valor econômico agregado (VEA) e estrutura de capital em empresas do IBRX 100. Anais dos seminários em administração, São Paulo, SP, Brasil, 20.

Banco Central do Brasil (2016). Série histórica da taxa SELIC. Recuperado em 10 junho, 2016 de http://www.bcb.gov.br/Pec/Copom/Port/taxaSelic.asp.

Bastos, D. D. \& Nakamura, W. T. (2009). Determinantes da estrutura de capital das companhias abertas do Brasil, México e Chile no período 2001-2006. Revista Contabilidade e Finanças, 20(50), 75-94.

Bernardelli, L. V. \& Bernardelli, A. G. (2016). Análise sobre a relação do mercado acionário com as variáveis macroeconômicas no período de 2004 a 2014. Revista Evidenciação Contábil \& Finanças, $4(1), 4-17$.

Borges Jr. D. M. et al. (2017). Endividamento de longo prazo e desempenho em tempos de crise: evidências de empresas no Brasil e América Latina. Revista Catarinense da Ciência Contábil, 16(47), 87-96.

Brealey, R. A. \& Myers, S. C. (1991). Principles of a corporate finance (4a ed.). Nova York: McGrawHill.

Brito, G. A. S., Corrar, L. J. \& Batistella, F. D. Fatores determinantes da estrutura de capital das maiores empresas que atuam no Brasil. Revista Contabilidade e Finanças, 18(43), 9-19, 2007.

Cagnin, R. F. et al. (2013). A gestão macroeconômica do governo Dilma (2011 e 2012). Novos estudos CEBRAP, 97, 169-185.

Costa Jr., A. F. \& Lemes Jr., A. B. (2006) Estrutura de capital das empresas integrantes do índice Ibx-Loo da bolsa de valores de São Paulo de 2000 a 2004. Salvador.

Durand, D. (1952). Cost of debt and equity funds for business: trends and problems of measurement. Conference on research on business finance, New York, Estados Unidos.

Espinola, L. F. P. (2013). Determinantes da estrutura de capital na crise financeira global. Dissertação de Mestrado, Universidade de São Paulo, São Paulo.

Fank, O. L., Angonese, R. \& Toledo Filho, J. R. (2010). Determinantes da estrutura de capital nas maiores empresas do Brasil. Anais do Encontro Nacional de Engenharia de Produção, São Carlos, SP, Brasil, 37.

Fávero, L. P. et al. (2009). Análise de dados: Modelagem multivariada para tomada de decisões. Rio de Janeiro: Campus. 
Faé, R., Goulart, S. \& Abdla, P. R. (2016). Estratégia nacional de desenvolvimento nos governos Lula e Dilma: Transformação Neoliberal. Revista Pensamento Contemporâneo em Administração, 10(1), 1-18.

Hair, J. F. et al. (2009). Análise mulivariada de dados. Bookman.

Iudícibus, S. (2009). Análise de balanços (10a ed.). São Paulo: Atlas.

Jorge, S. \& Armada, M. R. (2001). Factores determinantes do endividamento: uma análise em painel. Revista de Administração Contemporânea, 5(2), 9-31.

Laureano, G. L. (2008). Determinantes de curto e longo prazos das empresas brasileiras. Anais do Encontro da Anpad. Rio de Janeiro, RJ, Brasil, 32.

Lopes, F. P. et al. (2016). Desempenho econômico e financeiro das empresas brasileiras de capital aberto: um estudo das crises de 2008 e 2012, Revista Universo Contábil, 12(1), 105-121.

Lunardi, M. A. et al. (2017). Criação de valor no desempenho econômico de empresas familiares e não familiares brasileiras. Revista Evidenciação Contábil \& Finanças, 5(1), 94-112.

Mamede, S. P. N. et al. (2017). Empresas brasileiras estatais e não estatais: uma análise das relações de endividamento. Revista Evidenciação Contábil \& Finanças, 5(2), 4-22.

Maranho, F. S., Fonseca, M. W. \& Frega, J. R. (2016). Governança corporativa e desempenho das empresas diante da crise econômica Global de 2008: uma análise de dados em painel. Revista Adm. 9(2), 293-311.

Martins, H. C. \& Terra, P. R. S. (2015). Maturidade do endividamento, desenvolvimento financeiro e instituições legais: análise multinível em empresas latino-americanas. Revista Administração, 50(3), 381-394.

Matarazzo, D. C. (2010) Análise financeira de Balanços: Abordagem Gerencial (7a ed.). São Paulo: Atlas S.A.

Moreira, T. B. S. \& Soares, F. A. R. (2010). A Crise Financeira Internacional e as Políticas Anticíclicas no Brasil. Tema III: Política Fiscal e a Crise Econômica Internacional. Finanças Públicas. Prêmio Tesouro Nacional, 1-69.

Modigliani, F. \& Miller, M. (1958). The costs of capital, corporation finance, and the theory of investment. American Economic Review, 48(3), 261-297.

Nakamura, W. T., Martin, D. M. L. \& Kimura, H. (2004). Indicadores contábeis como determinantes do endividamento das empresas brasileiras. Anais do Encontro Nacional da Associação de Pós-Graduação e Pesquisa em Administração, Curitiba, PR, Brasil, 27.

Prazeres, R. V. et al. (2015). Fatores Determinantes do Endividamento: um Estudo Empírico no Setor de Telecomunicações Brasileiro. Contabilidade, Gestão e Governança, 18(2), 139-159.

Ristoff T. (2011). A internacionalização das empresas brasileiras no governo Lula: o BNDES como instrumento de política externa. Anais do Simpósio Nacional de História, São Paulo, SP, Brasil, 26.

Rosa, L. C. \& Costa, D. F. (2014). Efeitos da crise mundial de 2008 na situação econômica e financeira das empresas brasileiras que compõem o Ibovespa. Revista Mineira de Contabilidade, 15(53), 6-14.

Santos, C. M., Pimenta Júnior, T. \& Cicconi, E. G. (2009). Determinantes da escolha da estrutura de capital das empresas brasileiras de capital aberto: um survey. Revista de Administração, 44(1).

Sant'ana, J. A. A. (2001). A relação entre endividamento e rentabilidade nas empresas brasileiras de 1996 a 2000. 2001. 137f., Dissertação (Mestrado em Administração) - Universidade de Brasília, Brasília.

Silva, E. S. et al. (2016) Capital structure of Brazil, Russia, India and China by economic crisis. Revista de Administração Mackenzie, 17(3), 105-131. 
Santos, A. et al. (2013). A economia das empresas nos governos FHC e Lula: uma análise a partir da demonstração do valor adicionado. Revista Contabilidade e Controladoria, 5(1), 47-64.

Tristão, P. A. \& Dutra, V. R. (2012). Fatores que influenciam na estrutura de capital das empresas listadas na Bovespa. Revista de Administração da UFSM, 5, 309-320. 